\title{
The effect of steam curing on chloride penetration in geopolymer concrete
}

\author{
Januarti Jaya Ekaputri ${ }^{1,2, *}$, Inne Syabrina Mutiara ${ }^{2}$, Siti Nurminarsih $^{3}$, Nguyen Van $^{2}$ \\ $\mathrm{Chanh}^{4}$, Koichi Maekawa ${ }^{5}$ and Davin H. E. Setiamarga ${ }^{6 *}$ \\ ${ }^{1}$ Department of Civil Engineering, Institut Teknologi Sepuluh Nopember, Surabaya, East Java 60111, \\ Indonesia \\ ${ }^{2}$ Indonesian Consortium for Geopolymer Research, Institut Teknologi Sepuluh Nopember, Surabaya, \\ East Java 60111, Indonesia \\ ${ }^{3}$ Logistic Engineering Department, Indonesian International University for Cement Studies, Gresik, \\ East Java 61122, Indonesia \\ ${ }^{4}$ Faculty of Civil Engineering, Ho Chi Minh City University of Technology, Ho Chi Minh City, Ho \\ Chi Minh 70000, Vietnam \\ ${ }^{5}$ Department of Civil Engineering, The University of Tokyo, Bunkyo-ku, Tokyo, 113-0033, Japan \\ ${ }^{6}$ Department of Applied Chemistry and Biochemistry, National Institute of Technology, Wakayama \\ College, Gobo City, Wakayama 644-0023, Japan
}

\begin{abstract}
In this paper, we present the result of our study on the effect of steam curing to chloride ion penetration in geopolymer concrete. Class $\mathrm{F}$ fly ash was activated using sodium hydroxide $(\mathrm{NaOH})$ and sodium silicate $\left(\mathrm{Na}_{2} \mathrm{SiO}_{3}\right)$. The concrete specimens were then steam-cured at $40^{\circ} \mathrm{C}, 60^{\circ} \mathrm{C}$, $80^{\circ} \mathrm{C}$ and room temperature at 24 hours. The treatment was followed by wet curing for 28 days, and then followed by immersion of all specimens in salt water for the durations of 30,60 , and 90 days. Cylindrical specimens were then prepared for compressive strength, chloride ion penetration, $\mathrm{pH}$, and porosity tests. A $16 \mathrm{~mm}$-steel bar was fixed at the center of the specimen concrete blocks (specimen size: $10 \mathrm{~cm} \times 10 \mathrm{~cm} \times$ $15 \mathrm{~cm}$ ). Corrosion probability was determined by conducting Half Cell Potential test. Our result showed that increasing the curing temperature to $80^{\circ} \mathrm{C}$ induced chloride ion penetration into the concrete's effective pores, despite improvements in compressive strength. We also found that chloride ingress on the geopolymer concrete increases commensurately with the increase of the curing temperature. The corrosion potential measurement of geopolymer concrete was higher than OPC concrete even if corrosion was not observed in reinforcing. Based on our result, we suggest that the corrosion categorization for geopolymer concretes needs to be adjusted.
\end{abstract}

\section{Introduction}

Seawater greatly affects the strength of concrete for construction, especially on offshore buildings. High salt content gradually decreases the strength of concrete, causing a decrease on the durability of concrete significantly. Such breaches on concrete strength and

\footnotetext{
* Corresponding author: januartije@gmail.com and davin@wakayama-nct.ac.jp
} 
durability greatly affect the building's service life, and bring safety concerns at the same time. Previous studies have shown that the compromise of concrete strength caused by seawater is due to aggressive penetration of the chloride ions $\left(\mathrm{Cl}^{-}\right)$from the saltwater into the concrete [1]. Further $\mathrm{Cl}^{-}$ion penetrations deep into concrete pores was then followed by ion exchange reactions between the concrete and chloride ion, causing rebar corrosion and bond-lost between the concrete and the reinforcing materials (e.g. steel rebar). Therefore, in order to reduce the level of chloride ion penetration, concrete mixed with high volume of fly ash is commonly used to build concrete structures in aggressive environments $[2,3]$.

Previous studies have shown that geopolymer-concrete mix ("Geopolymer Concrete") has a strong resistance to corrosion [4]. Class $\mathrm{F}$ of fly ash, which is rich in silica and alumina, is usually used as the main binder in manufacturing of geopolymer concrete. Meanwhile, a liquid alkali solution containing $\mathrm{NaOH}$ and $\mathrm{Na}_{2} \mathrm{SiO}_{3}$ is commonly used to activate the fly ash in the concrete mixtures.

Chloride induced corrosion of the steel rebars in concrete is one of the most concerning durability issues for structures located at aggressive environments. Previously, the corrosion resistance of the reinforcement bar in geopolymer concrete have been studied by some researchers. They set to the effect of alkali solution or additional minerals in the mixtures $[5,6]$. It is found that the curing system, especially with steps involving drying, or wetting by immersion in water, influences the water adsorption level of geopolymer concrete. There are some curing methods to improve geopolymer concrete performance. However, only a few number of research have focused on the effect of steam curing on geopolymer concrete to resist chloride ion penetration.

Curing with oven, steam, wet or moist is the most recommended techniques. Differences in temperatures and curing durations may change concrete properties including the characteristics of concrete pores $[7,8]$. Past studies have confirmed that steam curing at a temperature range of $60^{\circ} \mathrm{C}-80^{\circ} \mathrm{C}$ contributes to faster strength development at early age [9] and promotes the reaction of geopolymerization $[10,11]$. On the other hand, some studies have suggested that moist curing is more recommended than wet curing [12]. Leaching of alkaline and some compound of alumina-silicates lead to the formation of more pores on the concrete surface. Porous concrete is an indication of a modification of microstructures in concrete, which changes its ability to resist chloride ion.

In this study, we report the result of our detailed investigation into the effect of moist curing using steam on the strength and durability of geopolymer concrete and its rebar, in order to elucidate if such method is effective to prevent the negative effect of chloride ion penetration. We believe our result presented here will provide a very useful insight to solve one of the key durability issues of geopolymer concrete.

\section{Materials and method}

First, we prepared fresh geopolymer concrete consisted of fly ash, sodium hydroxide $(\mathrm{NaOH})$, sodium silicate $\left(\mathrm{Na}_{2} \mathrm{SiO}_{3}\right)$, coarse aggregate, and fine aggregate. To guarantee mixture workability, superplasticizer (SP) from poly-carboxylate material was then applied, which amount was adjusted to be $2 \%$ weight-percentages against the weight of fly ash. $\mathrm{Na}_{2} \mathrm{SiO}_{3}$ composed of $13.7 \% \mathrm{Na}_{2} \mathrm{O} ; 17 \% \mathrm{SiO}_{2} ; 36.4 \% \mathrm{H}_{2} \mathrm{O}$. $\mathrm{NaOH}$ flake was diluted with distilled water to obtain a 8 molar solution. The ratio of $\mathrm{Na}_{2} \mathrm{SiO}_{3}$ to $\mathrm{NaOH}$ in alkali solution for all mixtures was kept constant at 2.5. Class F fly ash (ASTM C 618) 618 [13] was collected from a power plant in Gresik, Indonesia. The chemical composition of the ash by XRF testing is listed in Table 1. 
Table 1. Composition of chemical content of fly ash ( $\%$ by mass).

\begin{tabular}{|c|c|c|c|c|c|c|c|c|c|c|}
\hline $\mathrm{SiO}_{2}$ & $\mathrm{Al}_{2} \mathrm{O}_{3}$ & $\mathrm{Fe}_{2} \mathrm{O}_{3}$ & $\mathrm{TiO}_{2}$ & $\mathrm{CaO}$ & $\mathrm{MgO}$ & $\mathrm{Cr}_{2} \mathrm{O}_{3}$ & $\mathrm{~K}_{2} \mathrm{O}$ & $\mathrm{Na}_{2} \mathrm{O}$ & $\mathrm{SO}_{3}$ & $\mathrm{Mn}_{2} \mathrm{O}_{3}$ \\
\hline 48.47 & 26.05 & 12.54 & 0.92 & 5.18 & 2.77 & 0.02 & 1.66 & 0.47 & 1.05 & 0.19 \\
\hline
\end{tabular}

The weight ratio of the fly ash-containing binder to the total aggregate is 1:3. In addition, the binder has a mass ratio of $65 \%$ fly ash and $35 \%$ alkali activator. Geopolymer concrete specimens were cured in a temperature-humidity control room. The chamber was set to vary at $40^{\circ} \mathrm{C}, 60^{\circ} \mathrm{C}$, and $80^{\circ} \mathrm{C}$ for 24 hours. Specimens made of Ordinary Portland Cement (OPC) were prepared as a control system. One day after casting, all specimens were demolded and cured at a specific temperature in the chamber. The specimens were then subjected to wet curing in tap water for 28 days before exposing to the chlorideinduced system. The composition of concrete is shown in Table 2.

Table 2. Composition of mixtures $\left(\mathrm{Kg}\right.$ per $\left.\mathrm{m}^{3}\right)$.

\begin{tabular}{|c|c|c|c|c|c|c|c|c|c|}
\hline Code & $\begin{array}{c}\text { Fine } \\
\text { aggregate }\end{array}$ & $\begin{array}{c}\text { Coarse } \\
\text { aggregate }\end{array}$ & $\begin{array}{c}\mathrm{Fly} \\
\text { ash }\end{array}$ & $\mathrm{OPC}$ & $\mathrm{NaOH}$ & Water & $\mathrm{Na}_{2} \mathrm{SiO}_{3}$ & $\mathrm{SP}$ & $\begin{array}{c}\text { Curing } \\
\text { Temperature }\end{array}$ \\
\hline $\mathrm{GN}$ & 720 & 1080 & 390 & - & 60 & - & 150 & 7.8 & Room temp. \\
\hline $\mathrm{G} 40$ & 720 & 1080 & 390 & - & 60 & - & 150 & 7.8 & $40^{\circ} \mathrm{C}$ \\
\hline $\mathrm{G} 60$ & 720 & 1080 & 390 & - & 60 & - & 150 & 7.8 & $60^{\circ} \mathrm{C}$ \\
\hline $\mathrm{G} 80$ & 720 & 1080 & 390 & - & 60 & - & 150 & 7.8 & $80^{\circ} \mathrm{C}$ \\
\hline OPC & 666 & 999 & - & 440 & - & 220 & - & - & Room temp. \\
\hline
\end{tabular}

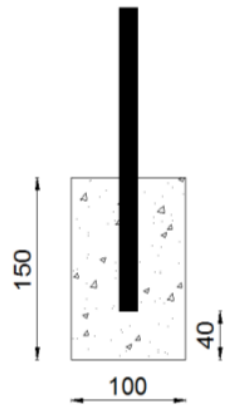

(a)

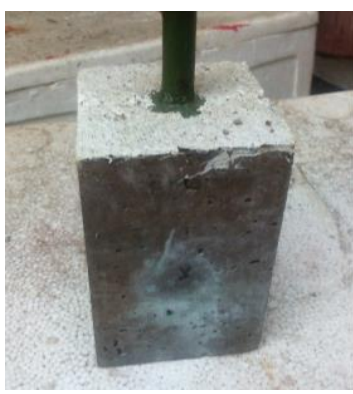

(b)

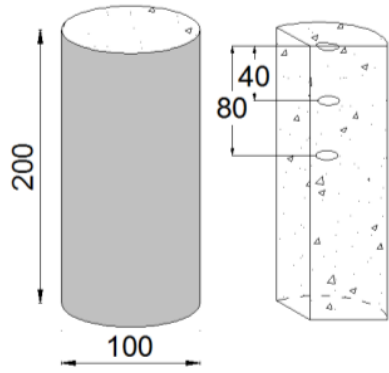

(c)

Fig. 1. (a) size of lollypop specimen in mm, (b) coating at top side, (c) cylindrical specimen.

Three identical lollypop-shape specimens with the dimension of $100 \mathrm{~mm}$ wide, $150 \mathrm{~mm}$ long, and $40 \mathrm{~mm}$ deep (Fig 1(a), (b)) were used as samples in the chloride induction study. Each block of geopolymer concrete specimens has a $16 \mathrm{~mm}$ diameter-steel bar set as rebar. The top side of concrete and the bar were coated to prevent direct chloride penetration. The corrosion activity is monitored by measuring the copper/copper sulphate $\left.(\mathrm{Cu} / \mathrm{CuSO})_{4}\right)$ halfcell potential according to ASTM C-876 [14]. In each variable, three identical cylinders of $100 \mathrm{~mm}$ in diameter and $200 \mathrm{~mm}$ in height were prepared for the comparison samples in some tests, such as compressive strength, chloride content, $\mathrm{pH}$ and porosity (Fig. 1(c)). Except for the top and bottom side, the surface of all cylinders was covered with a waterproof coating. The specimens were subjected to wet curing in water containing $3.5 \%$ $\mathrm{NaCl}$ salt for 30,60 and 90 days. The saline water was replaced with fresh salt solution every week. Tests for chloride penetration depth and $\mathrm{pH}$ were targeted at some points in each cylindrical specimen as illustrated in Fig 1 (c). 


\section{Results and discussion}

\subsection{Compressive strength}

The result of the compressive strength test is presented in Table 3. Because steam curing induces faster concrete maturity, the 28 days specimen G80 showed the highest strength, with the optimal curing temperature at $80^{\circ} \mathrm{C}$. Temperature increase is known to increase compressive strength, because it accelerates geopolymerization reaction [15]. This also means that heating causes microstructural properties changes in geopolymer concretes. In our previous study, we reported mechanical properties and elastic modulus changes of geopolymer concrete, due to steam curing, it was found that the mechanical properties change and the elastic modulus on geopolymer concrete due to steam curing. Water evaporation and self-desiccation during the heat curing stage was also reported by Wardhono et al [16]. They found that the $\mathrm{Si} / \mathrm{Al}$ ratio in the matrix decreased with age indicating an on-going geopolymerization process beyond the 90 day time period. In this condition, continuous gel formation filled up the voids. This is most likely the explaination of the increasing of strength observed in the GN and G40 specimens.

Table 3. Compressive strength of cylindrical specimens.

\begin{tabular}{|c|c|c|c|c|}
\hline Age (days) & 28 & 60 & 90 & 120 \\
\hline Immersion time (days) & \multicolumn{5}{|c|}{ Compressive strength (MPa) } \\
\hline Code & \multicolumn{4}{|c|}{60} \\
\hline GN & 51.1 & 64.7 & 67.5 & 69.5 \\
\hline G40 & 63.3 & 60.2 & 63.5 & 70.9 \\
\hline G60 & 59.3 & 62.5 & 68.0 & 66.2 \\
\hline G80 & 78.7 & 78.9 & 80.5 & 74.5 \\
\hline OPC & 46.6 & 52.3 & 60.1 & 58.1 \\
\hline
\end{tabular}

In Fig. 2, the compressive strength of all specimens at the age of 120 days is actually higher than the strength at 28 days. However, the strengths of specimens GN60 and GN80 increased until the $60^{\text {th }}$ day of immersion, but they decreased gradually until the $90^{\text {th }}$ day of immersion. In addition, the strength of OPC specimen, which was cured in room temperature, shows the same tendency to decrease after the $60^{\text {th }}$ day of immersion. This is due to chloride ion penetration into the concrete pores and precipitation forms as a reaction of chloride ion with calcium mineral constituents, causing a drastic decrease of strength in OPC concrete specimens.

Improved strength of geopolymer specimens when cured in salt water is believed to be related to reduced leaching of alkali activator from the geopolymer concretes to the salt water curing [17]. This mechanism is greater than the effect of intrusion of natrium contained in salt water into the geopolymer specimens. Saline water shield solution for geopolymer most likely help to prevent leaching, and thus explains strength increase when the concrete is subjected to salt water. After casting followed by steam curing, all samples were cured in tap water for 27 days. This might cause alkali leaching of all geopolymer samples. This caused more pores in concrete surface formed generally during wet curing. After 28 days, when all samples were cured in salt water, the leaching is apparently decreased gradually and possibly prevented by excess $\mathrm{Na}^{+}$cations in the surrounding curing system. At later age, decreased strength is associated by formation of inorganic salts in aluminosilicate gel due to ion exchange. Giasuddin et al reported that at ambient temperature, saline water is better for geopolymer curing when compared to freshwater 
curing system, because important reactant elements might be leached out from the geopolymer sample to the curing medium in the freshwater system.

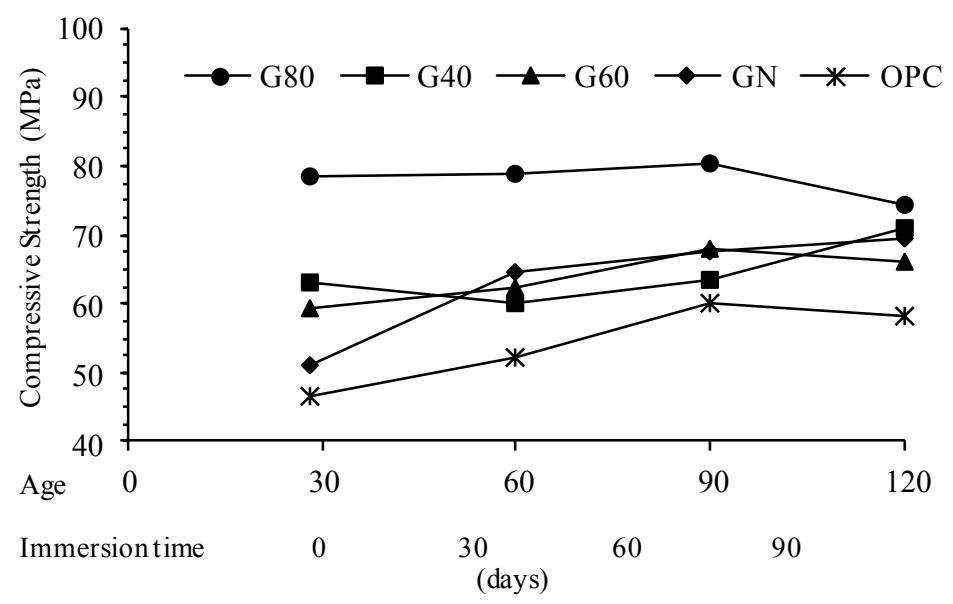

Fig. 2. Compressive strength of specimens curing in salt water.

\subsection{Porosity test}

Samples for porosity test were selected at the same sample for compressive strength test. Total porosity and closed porosity of all samples are presented in Fig. 3 (a) and Fig 3 (b) respectively. Closed porosity is a percentage of pore space measured by boiling the saturated concrete for five hours. Porosity is the total pores contributed by closed and effective porosity (Fig 3 (c)). However, effective pores have more influence to promote total porosity formation. These results are in good agreement with Kovalchuk et al [18], where the total porosity of $15 \%$ was found on geopolymer products subjected to steam curing.

Due to greater reaction occurred in steam curing, all geopolymer samples cured at $40^{\circ} \mathrm{C}$, $60^{\circ} \mathrm{C}$, and $80^{\circ} \mathrm{C}$ showed less porosity than specimen GN and OPC at the age of 28 days. Heating mixture contributed not only to the increase of the geopolymer concrete strength, but it also limited the pore size, especially of the effective pores, in the geopolymer paste. During steam curing, geopolymerization process occurred rapidly. When small quantity of water involved in the mixture, which was excluded in the reaction, it was entrapped and filled the closed pores. This is different from reaction occurred in the geopolymer specimen cured at room temperature. Since the reaction is slower, more fly ash particles, aluminosilicate gel, and silicate gel remained un-reacted. Total pores of GN sample is greater than steam cured specimens is associated with leaching of some unreacted constituents to surrounding water from the age of two days to 28 days. Olivia and Nikraz suggested a linear correlation between porosity increase with the decrease of compressive strength [19]. Significant change of porosity is shown by OPC sample in Fig 3(a). This contributes to the decrease of concrete strength immersed for 90 days in salt water. 


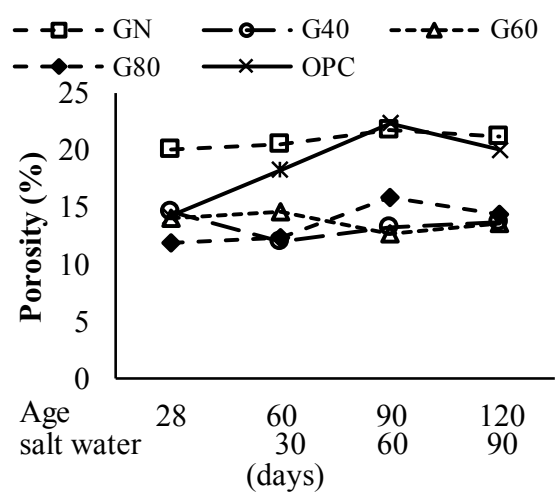

(a)

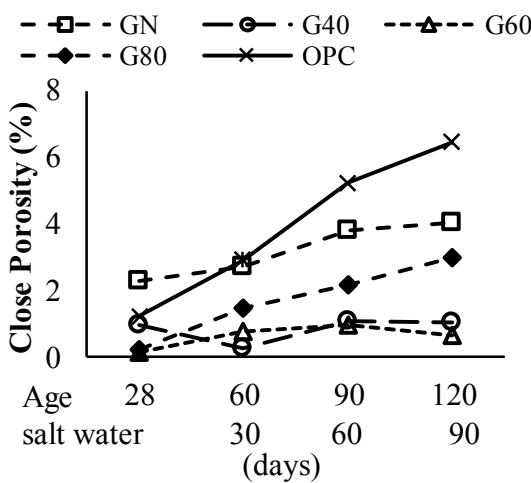

(b)

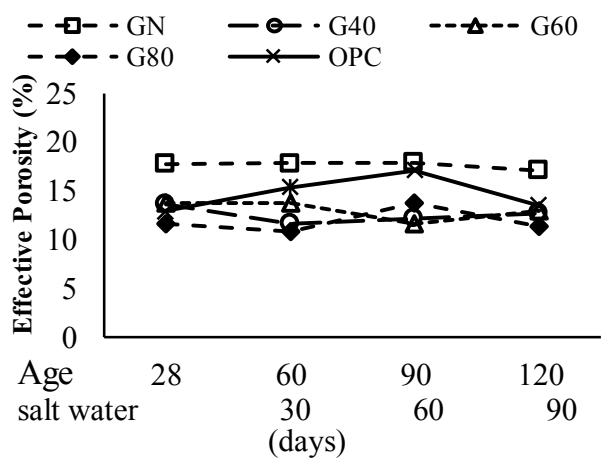

(c)

Fig. 3. Porosity test results: (a) Total porosity, (b) closed porosity, and (c) effective porosity.

\subsection{Chloride penetration}

Fig. 4 presents the chloride content of the specimens at a depth of $0 \mathrm{~cm}, 4 \mathrm{~cm}$, and $8 \mathrm{~cm}$ from concrete surface. The chloride content at concrete surface was quite high, especially at the steamed-curing specimens. The maximum chloride content at G40, G60, and G80 were in a range of $1.2 \%, 1.5 \%$, and $1.4 \%$ respectively. Reduction of chloride content at a depth of $4 \mathrm{~cm}$ and $8 \mathrm{~cm}$ was observed but the chloride content is much higher than specimens cured in room temperature. The lowest chloride concentration among the samples was performed by OPC at a depth of $8 \mathrm{~cm}$, which was only $0.04 \%$.

High chloride concentration in the geopolymer matrix could be due to the absence of a chloride binding mechanism or chloride ion exchange in the sodium-aluminosilicate $(\mathrm{N}-\mathrm{A}-$ $\mathrm{S}-\mathrm{H})$ gel system. It is observed at samples G40, G60, and G80. Active chemical reaction in geopolymer concrete exposed to steam curing was observed to happen at early ages (24 hours). This caused early maturity of reactions, causing the subsequent continuous reaction to be very much slower at higher temperature. Smaller size of effective pores formed in the matrix was expected to increase water absorption. This is slightly different from samples where the continuous reaction between alkali activator and un-reacted fly ash particle gradually occurred with the presence of both cation $\mathrm{Na}^{+}$as shield solution and ion $\mathrm{Cl}$ ingress to the pores. A similar result was observed by Olivia and Nikraz [20]. When geopolymer concrete was cured at $60^{\circ} \mathrm{C}-75^{\circ} \mathrm{C}$, geopolymer concrete showed better 
mechanical properties than OPC concrete and lower porosity, but chloride ion concentration was found much higher in geopolymer concrete.
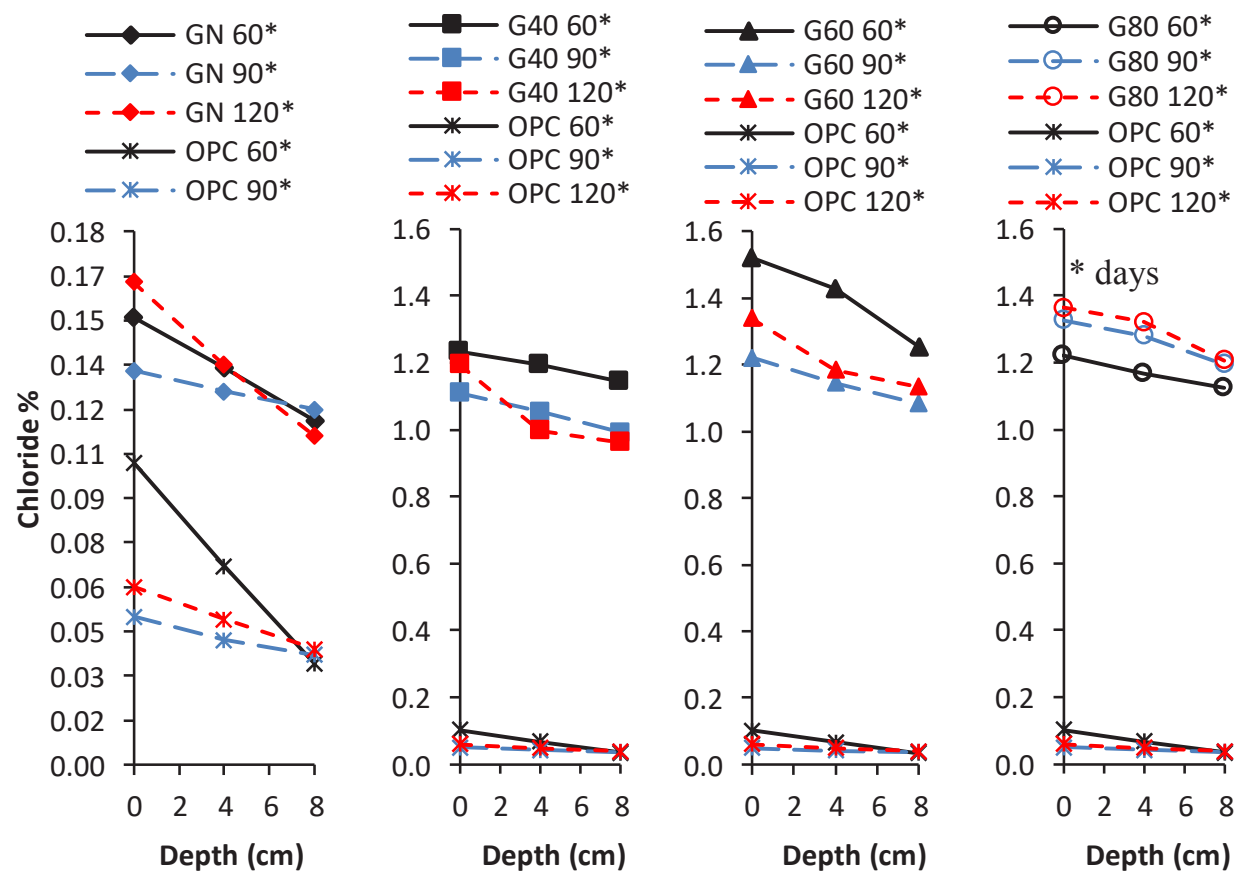

Fig. 4. Chloride ion penetration at several distances from the concrete surface.

\section{$3.4 \mathrm{pH}$ in concrete}

$\mathrm{pH}$ measurement is related to chloride ingress to penetrate concrete pores. Fig. 5 shows that $\mathrm{pH}$ of geopolymer specimens is lower than $\mathrm{pH}$ of OPC. Besides the fact that geopolymer has lower $\mathrm{pH}$ than $\mathrm{OPC}$, water curing caused leaching contributed to concrete $\mathrm{pH}$ decreased. Higher $\mathrm{pH}$ at the deeper surface of geopolymer specimens subjected to heating shows contradictory results from chloride penetration. When the chloride ingress was found greatly in the samples, the $\mathrm{pH}$ is surprisingly similar to that at GN sample. It indicates that chloride ion is not involved during the formation of aluminosilicate gel to lower $\mathrm{pH}$ of geopolymer product. A common low $\mathrm{pH}$ of geopolymer concrete compared to OPC concrete was also reported by Babaee and Castel [21]. 


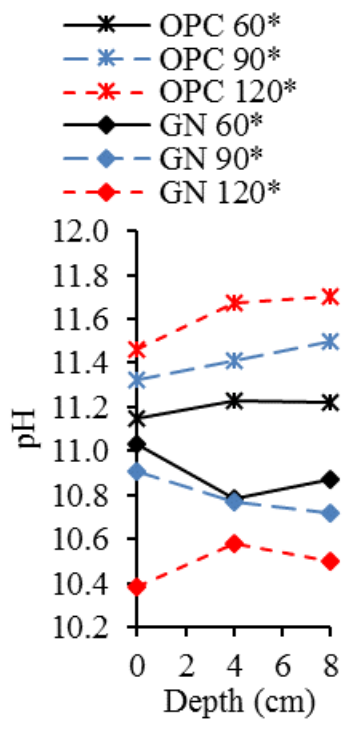

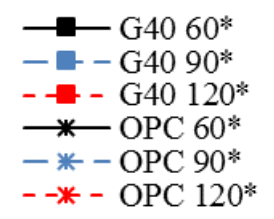

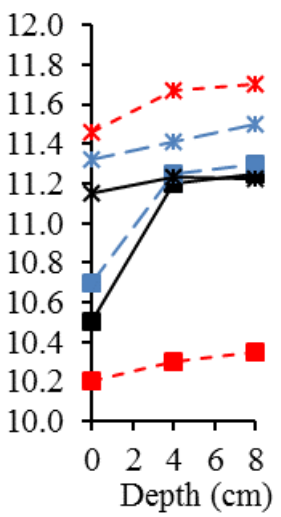

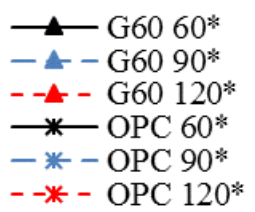

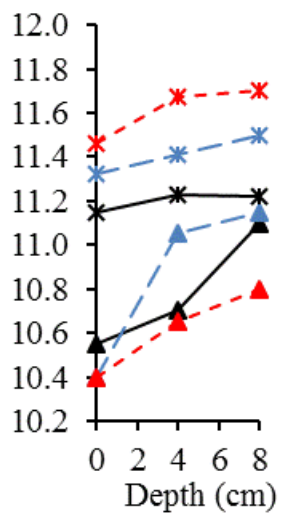

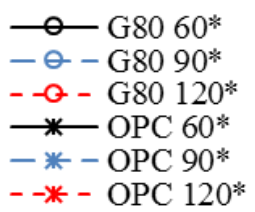

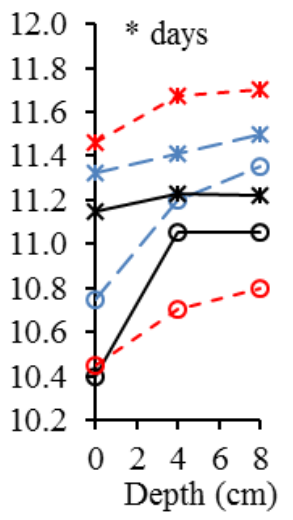

Fig. 5. $\mathrm{pH}$ measurement.

\subsection{Corrosion potential}

Corrosion potential was measured using $\mathrm{Cu} / \mathrm{CuSO}_{4}$ electrode mounted on the end of the $16 \mathrm{~mm}$ diameter reinforcement steel bar of the lolypop test specimen. Measurements are made by connecting the rebars and electrodes to the high impedance digital multi meter.

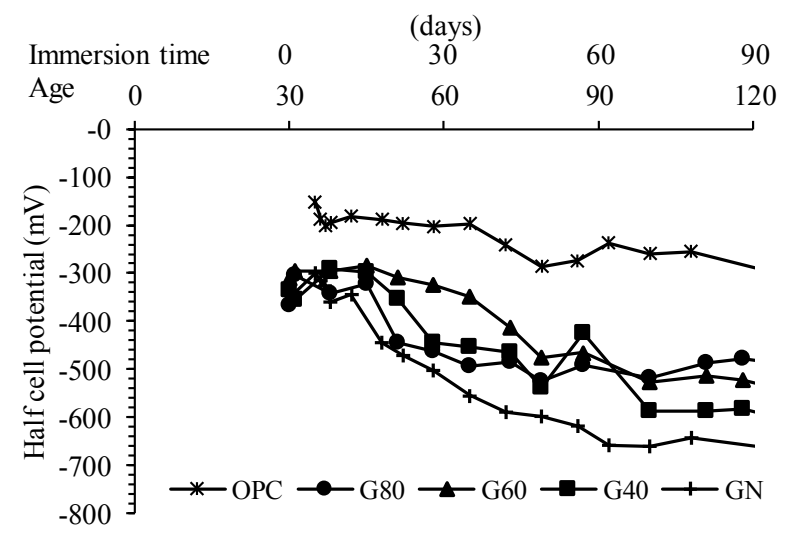

Fig. 6. Half-cell potential measurement.

Fig. 6 indicates that the overall potential of corrosion increases at longer duration of immersion. It is possibly due to the effects of longer exposure time to chloride ions penetration. The half-cell potential of geopolymer concrete at the beginning reached the range between -300 to $-500 \mathrm{mV}$. At the end of immersion period, it was in the range of $470 \mathrm{mV}$ to $-670 \mathrm{mV}$. All geopolymer concretes showed negative corrosion rate potentials greater than $-500 \mathrm{mV}$, which were more negative than those of the OPC concrete samples. It is apparently caused by the chloride ions penetration. According to ASTM C 876, this potential value is categorized as $90 \%$ probability of corrosion. As a result, we can conclude that the lower initial alkalinity of geopolymer concrete certainly leads to more negative corrosion potential values. 


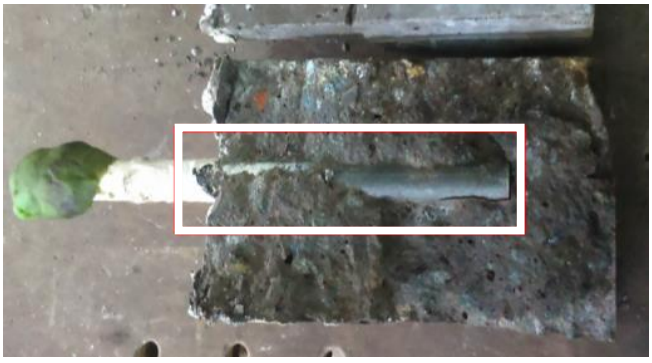

(a)

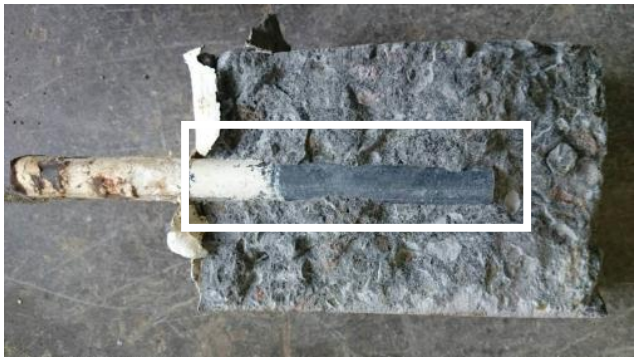

(b)

Fig. 7. After curing in salt water for 90 days (a) G80 specimen, (b) OPC specimen.

Fig. 7 shows the physical condition of reinforcing bars embedded into the geopolymer concrete (a) and OPC concrete (b) after immersing in salt water for 90 days at an ambient temperature. Surprisingly, no corrosion was observed around the steel bar. Although the half-cell potential value is categorized as $90 \%$ probability of corrosion in geopolymer specimens, there is no rust on the steel bar in the concrete. This could be considered as one of the evidence that geopolymer concrete strength remains high at the end of immersion time. From this finding, we would like to suggest that the conventional method of the classification system of concrete and rebar corrosions, which was developed based on observations and research on Portland cement-based specimens, needs to be adjusted for geopolymer-based systems.

\section{Conclusions}

1. Steam curing at $80^{\circ} \mathrm{C}$ for 24 hours resulted in the highest compressive strength of geopolymer concrete at 28 days. This is because fly ash reacts slower at room temperature than steam curing system. Steam curing increased the kinetics and reaction rates during the geopolymerization process, causing the development of denser pore system, to produce good mechanical properties

2. After immersion for 90 days in saline solution or at 120 days of age, compressive strength of concrete cured at room temperature increased by $32-36 \%$ of its 28 -day strength. Strength of geopolymer concrete subjected to higher temperature increased by $12-33 \%$ of its 28 -day strength. This caused mainly by leaching of $\mathrm{Na}^{+}$as the fly ash activator was prevented by salt water, which surrounded the concrete, resulted in continuous reaction of geopolymerization during immersions.

3. Although the compressive strength of geopolymer concrete increased due to steam curing, chloride concentration also increased. The corrosion rate value using half-cell potential for all geopolymer concrete was in the range of -470 to $-670 \mathrm{mV}$, which was categorized as $90 \%$ probability in corrosion. However, no rust was found on the reinforcing concrete of geopolymer. The high potential-value is probably due to the low $\mathrm{pH}$ of the concrete and the high concentration of chloride in the concrete. Based on this finding, we suggest that different standardized values and settings are needed to measure the corrosion potential of geopolymer concrete.

\section{References}

1. J.J. Ekaputri, and Triwulan, "Forensic engineering: From failure to understanding". (2008) 
2. T. Cheewaket, C. Jaturapitakkul, and W. Chalee, "Construction and Building Materials", 37, 693-698 (2012)

3. V. Saraswathy, and H.W. Song, 51 (22), 4601-4611 (2006)

4. K. Zerfu, and J.J. Ekaputri, Materials Science Forum, 841, 162-169 (2016)

5. M. Rostami, and K. Behfarnia, "Construction and Building Materials", 134, 262-268 (2017)

6. F.U.A. Shaikh, "Advances in concrete construction", 2 (2), 109-123 (2014).

7. J. J. Ekaputri, K. Maekawa, and T. Ishida, "Materials Science Forum", 857, 305-310 (2016)

8. J.J. Ekaputri, S. Junaedi, and Wijaya, Procedia Engineering, 171, 572-583 (2017)

9. M.M.A. Abdullah, et al., "Advanced Materials Research", 328-330, 1475-1482 (2011)

10. D. Hardjito, et al., "Civil Engineering Dimension", 6 (2), 88-93 (2004)

11. J.J. Ekaputri, et al., "Materials Science Forum", 803, 63-74 (2014)

12. Halim, L.N., J.J. Ekaputri, and Triwulan, MATEC Web of Conferences, 97 (2017)

13. American Society for Testing and Material, ASTM, C618-03, (2003)

14. American Society for Testing and Material ASTM, C876-09, (2015)

15. Triwulan, J.J. Ekaputri, and N.F. Priyanka, MATEC Web of Conferences (2016)

16. A. Wardhono, et al., "Construction and Building Materials", 143, 272-279 (2017)

17. H. M. Giasuddin, J. G. Sanjayan, and P.G. Ranjith, "Fuel", 107, 34-39 (2013)

18. G. Kovalchuk, A. Fernández-Jiménez, and A. Palomo, "Fuel", 86 (3), 315-322 (2007).

19. M. Olivia, and H.R. Nikraz, ARPN Journal of Engineering and Applied Sciences, 6 (7) 70-78 (2011)

20. M. Olivia, and H.R. Nikraz. The Concrete Institute of Australia (2011)

21. M. Babaee, and A. Castel, "Cement and Concrete Research", 88, 96-107 (2016) 